DOI: $10.19195 / 0137-1134.109 .9$

\title{
ROLA PREZESA URZĘDU ZAMÓWIEŃ PUBLICZNYCH W ZAPOBIEGANIU I ZWALCZANIU NADUŻYĆ WOLNOŚCI KONTRAKTOWEJ W UMOWACH ZAWIERANYCH W RAMACH ZAMÓWIEŃ PUBLICZNYCH
}

Celem niniejszego opracowania jest określenie zadań Prezesa Urzędu Zamówień Publicznych (UZP) oraz roli, jaką sprawowany przez niego nadzór nad rynkiem zamówień publicznych powinien odgrywać w przeciwdziałaniu oraz zwalczaniu różnego rodzaju przejawów nadużycia wolności kontraktowej w umowach zawieranych na tym rynku. Wskazanemu zagadnieniu jak dotychczas nie poświęca się należytej uwagi w literaturze przedmiotu, tymczasem zważywszy na liczne niedomagania i niewydolności zachodzące na rynku zamówień publicznych, nabiera ono coraz większego znaczenia, zarówno w wymiarze teoretycznym, jak i praktycznym. Do nadużyć wolności kontraktowej w zamówieniach publicznych dochodzi najczęściej w związku ze stosowaniem przez zamawiających wzorców umownych jednostronnie kształtujących prawa i obowiązki wykonawców. Brak indywidualnego uzgadniania treści umów sprzyja bowiem narzucaniu wykonawcom postanowień umownych naruszających granice prawnie chronionej wolności, które zostały wyznaczone przez naturę stosunków zobowiązaniowych oraz ustawy i zasady współżycia społecznego (zob. art. $353^{1}$ W zw. z art. 384 k.c. ${ }^{1}$ ). Obok wzorców umownych nie mniej ważnym czynnikiem przyczyniającym się do nadużyć wolności kontraktowej w zamówieniach publicznych jest bezpodstawne utożsamianie interesu zamawiających z interesem publicznym, motywowane koniecznością ochrony finansów publicznych. Należyte zabezpieczenie środków publicznych oraz ich racjonalne wydatkowanie nie wymaga jednak ani nie usprawiedliwia stosowania nieuczciwych praktyk umownych. Zarówno dążenie do osiągania różnych celów społecznych poprzez zamówienia publiczne, jak i specyfika ich regulacji prawnej nie stanowią stanu wyższej konieczności, który mógłby uzasadniać poświęcenie jednych wartości kosztem drugich. Przeciwdziałanie oraz zwalczanie nadużyć wol-

${ }^{1}$ Ustawa z dnia 23 kwietnia 1964 r. — Kodeks cywilny (tekst jedn. Dz.U. 2014 poz. 121 z późn. zm., dalej: k.c.). 
ności kontraktowej z całą pewnością leży w interesie publicznym, a tolerowanie ich stosowania inspirowane publicznoprawnymi celami zamówień publicznych nierzadko prowadziło już w przeszłości do istotnego i nieprzewidywalnego zwiększenia wydatków publicznych (np. przy realizacji kontraktów drogowych). Ponieważ przekroczenie granic wolności kontraktowej zasadniczo skutkuje nieważnością umów w całości lub w części (zob. art. 58 k.c.), co w rezultacie powoduje zniweczenie celów, jakie z woli prawodawcy mają być realizowane przez zamówienia publiczne, zapobieganie powstawaniu takich nieprawidłowości staje się kwestią o pierwszorzędnym znaczeniu. Nasuwają się zatem istotne pytania i wątpliwości, czy na gruncie obowiązujących przepisów Prezes UZP właściwie sprawuje nadzór nad rynkiem zamówień publicznych w zakresie przeciwdziałania i eliminowania nadużyć wolności kontraktowej, czy też powinien on raczej zweryfikować swoją praktykę? Czy ustawowo określone zadania Prezesa UZP oraz stworzone przez ustawodawcę środki w ramach sprawowanego przez niego nadzoru nad zamówieniami publicznymi stanowią skuteczne i wystarczające narzędzia zapobiegania nadużyciom wolności kontraktowej oraz zwalczania ich przejawów? Czy też konieczna jest zmiana obowiązujących w tym obszarze przepisów? Podjęcie wskazanej problematyki uzasadnione jest również potrzebą oceny różnych negatywnych zjawisk w obrocie wywołanych rezygnacją przez ustawodawcę na gruncie zamówień publicznych z sankcji nieważności czynności prawnych w całości lub w części w związku z naruszeniem przepisów ustawy².

Zadania Prezesa UZP, który jest centralnym organem administracji rządowej (publicznej, gospodarczej) podległym bezpośrednio Prezesowi Rady Ministrów, zostały uregulowane w ustawie Prawo zamówień publicznych ${ }^{3}$. Zgodnie z art. 154 u.z.p. Prezes opracowuje projekty aktów normatywnych dotyczących zamówień publicznych, podejmuje rozstrzygnięcia $\mathrm{w}$ sprawach indywidualnych przewidzianych $\mathrm{w}$ ustawie, wydaje $\mathrm{w}$ formie elektronicznej Biuletyn Zamówień Publicznych, w którym zamieszcza się ogłoszenia wymagane przepisami ustawy, prowadzi i ogłasza na stronie internetowej urzędu listę organizacji uprawnionych do wnoszenia środków ochrony prawnej, zapewnia funkcjonowanie systemu środków ochrony prawnej, opracowuje program szkoleń oraz organizuje i inspiruje szkolenia z zakresu zamówień publicznych, przygotowuje i upowszechnia przykładowe kryteria oceny merytorycznego poziomu szkoleń, przygotowuje i upowszechnia przykładowe wzory umów w sprawach zamówień publicznych, regulaminów oraz innych dokumentów stosowanych przy udzielaniu zamówień, czuwa nad przestrzeganiem zasad systemu zamówień publicznych, w szczególności

2 Zniesienie sankcji nieważności związanej z określonymi naruszeniami przepisów prawa zamówień publicznych i wprowadzenie swoistego dualizmu sankcji nastąpiło na mocy ustawy z dnia 2 grudnia 2009 r. o zmianie ustawy — Prawo zamówień publicznych oraz niektórych innych ustaw (Dz.U. 2009 Nr 223, poz. 1778).

${ }^{3}$ Ustawa z dnia 29 stycznia 2004 r. — Prawo zamówień publicznych (tekst jedn. Dz.U. 2015 poz. 2164), dalej: u.z.p. 
przez kontrolę procesu udzielania zamówień w zakresie przewidzianym ustawą, upowszechnia zasady etyki zawodowej osób wykonujących zadania w systemie zamówień publicznych, dąży do zapewnienia jednolitego stosowania przepisów o zamówieniach publicznych przy uwzględnieniu orzecznictwa sądów i Trybunału Konstytucyjnego (TK), w szczególności przez upowszechnianie orzecznictwa Krajowej Izby Odwoławczej (KIO), sądów oraz TK dotyczącego zamówień publicznych, prowadzi współpracę międzynarodową w sprawach związanych z zamówieniami publicznymi, dokonuje analiz funkcjonowania systemu zamówień publicznych, opracowuje i przedstawia Radzie Ministrów, Komisji Europejskiej oraz właściwej komisji Sejmu roczne sprawozdania o funkcjonowaniu systemu zamówień publicznych, w tym obejmujące wykonanie zadania polegającego na upowszechnianiu przygotowanych wzorów umów, regulaminów i innych dokumentów w sprawach zamówień publicznych, przedstawia Prezesowi Rady Ministrów roczną informację o działaniu KIO oraz problemach wynikających z orzecznictwa, a także nie rzadziej niż raz na trzy lata plan wykonania w latach następnych zadania polegającego na upowszechnieniu przygotowywanych wzorów umów, regulaminów i innych dokumentów w sprawach zamówień publicznych, zgłasza kandydatów na Prezesa i wiceprezesa KIO oraz wnioskuje o powołanie rzecznika dyscyplinarnego KIO, prowadzi działania związane z informatyzacją systemu zamówień publicznych oraz corocznie do dnia 31 marca przekazuje Komisji Europejskiej wyroki KIO wraz z ich uzasadnieniem z roku poprzedniego, dotyczące odwołań w sprawach postępowań o udzielenie zamówienia, w których zaniechano unieważnienia umowy ze względu na ważny interes publiczny.

Przepis art. 154 u.z.p. wymienia sporą liczbę różnych zadań Prezesa UZP, jednak nie tworzy ich zamkniętego katalogu ani też nie stanowi zbioru zadań o jednakowym charakterze. Poza jego treścią znajdują się m.in. zadania z zakresu kontroli postępowań o udzielenie zamówień publicznych (zob. art. 161 ust. 1 u.z.p.), rozpatrywania zastrzeżeń zamawiających do przekazanych im informacji o wynikach kontroli (zob. art. 167 ust. 2 u.z.p.), nakładania i egzekwowania kar pieniężnych (zob. art. 168 pkt 2 w zw. $z$ art. 199 i n. u.z.p. oraz art. 195 ust. 2 u.z.p.), występowania do sądów w sprawach o unieważnienie umowy w całości lub w części w wypadku ujawnienia naruszenia przepisów ustawy (zob. art. 168 pkt 2 w zw. z art. 198b ust. 4 u.z.p.), a w wypadku czynów naruszających jednocześnie dyscyplinę finansów publicznych — zawiadamiania właściwego rzecznika finansów publicznych (zob. art. 168a u.z.p.), a także składania skarg kasacyjnych od orzeczeń sądów kontrolujących rozstrzygnięcia KIO w sprawach dotyczących niezgodności z przepisami ustawy dokonania czynności zamawiającego lub jej zaniechania w postępowaniu o udzielenie zamówienia publicznego (zob. art. 198g u.z.p.). Ponadto, choć nie zostało to wyrażone wprost $\mathrm{w}$ przepisach ustawy, Prezes UZP kieruje również pracą Urzędu Zamówień Publicznych, reprezentuje go na zewnątrz oraz na podstawie przewidzianych w obowiązujących przepisach narzędzi za jego pomocą nadzoruje w Polsce rynek zamówień publicznych (por. art. 154 pkt 11 u.z.p.). Przepisy 
ustawy Prawo zamówień publicznych, będące główną podstawą sformułowania zadań Prezesa UZP, tworzą normy o charakterze zadaniowym, normy określające zakres działania organu administracji centralnej, normy kompetencyjne oraz normy materialnoprawne ${ }^{4}$, przy czym każdy z rodzajów tych norm osobno lub łącznie może wynikać z jednego lub kilku przepisów ustawy. Dotyczy to też art. 154 u.z.p., który zawiera syntetyczne wyliczenie różnych zadań Prezesa UZP, pomimo iż przepis ten został umiejscowiony w rozdziale pierwszym działu piątego zatytułowanym „Zakres działania”, co może bezzasadnie sugerować, że jest on źródłem wyłącznie norm określających zakres działania organu administracji centralnej. Podział wskazanych norm, pomijając fakt, iż nie można przypisać mu w pełni cech rozłączności, odgrywa istotne znaczenie. Ich rozróżnienie umożliwia bowiem ustalenie nie tylko sposobu i dopuszczenia ewentualnej swobody wykonywania obowiązków powierzonych przez ustawodawcę zadań, lecz także skutków ich niewykonania lub nienależytego wykonania. Generalnie rzecz ujmując, Prezes UZP nie może zaniechać wykonywania lub wadliwie wykonywać zadań określonych za pomocą norm zadaniowych (zadania sensu stricto). Wywiązywanie się z tego rodzaju zadań przez Prezesa UZP objęte jest kontrolą i nadzorem Prezesa Rady Ministrów, a także leży w obszarze kognicji Najwyższej Izby Kontroli ${ }^{5}$. Z kolei normy wytyczające zakres działania Prezesa UZP wskazują na właściwość tego organu administracji publicznej w poszczególnych rodzajach spraw objętych regulacją ustawy Prawo zamówień publicznych. Normy kompetencyjne w ramach właściwości organu wskazują na upoważnienie Prezesa UZP odnośnie do możliwości podejmowania przez niego różnych abstrakcyjnie określonych działań w przewidzianych prawem formach ${ }^{6}$, zarówno wewnątrz organu administracji publicznej, jak i na zewnątrz. Upoważnienia kompetencyjne oparte są w głównej mierze na przepisach prawa materialnego, a ich prawidłowe wypełnianie również podlega kontroli oraz nadzorowi i może wiązać się z odpowiedzialnością. Normy materialnoprawne stanowią natomiast podstawę działalności jurysdykcyjnej i służą Prezesowi UZP do podejmowania konkretnie oznaczonych decyzji, w tym kształtujących prawa i obowiązki podmiotów uczestniczących w rynku zamówień publicznych. Warto też zaznaczyć, że wszystkie wyróżnione normy, z wyjątkiem norm zdaniowych, które nigdy nie są podstawą rozstrzygnięć Prezesa UZP w sprawach indywidualnych dotyczących

${ }^{4} \mathrm{Na}$ temat pojęcia oraz roli wskazanych norm zob. bliżej K. Kiczka, System Prawa Administracyjnego. Publiczne Prawo Gospodarcze, red. R. Hauser, Z. Niewiadomski, A. Wróbel, Warszawa 2013, t. 8B, s. 447 n. oraz powołana tam literatura.

5 Zob. art. 2 ust. 1 ustawy z dnia 23 grudnia 1994 r. o Najwyższej Izbie Kontroli (tekst jedn. Dz.U. 2015 poz. 1096, dalej: unik), w zw. z art. 203 ust. 1 Konstytucji Rzeczypospolitej Polskiej z dnia 2 kwietnia 1997 r. (Dz.U. 1997 Nr 78, poz. 483 z późn. zm., dalej: Konstytucja RP).

${ }^{6}$ Zob. bliżej na ten temat K.M. Ziemski, System Prawa Administracyjnego. Prawne formy działania administracji, t. 5, red. R. Hauser, Z. Niewiadomski, A. Wróbel, Warszawa 2014, s. 3 n. Por. M. Kania, K. Kiczka, M. Szydło, Specyfika prawnych form działania administracji gospodarczej, [w:] System Prawa Administracyjnego. Publiczne Prawo..., t. 8B, s. 447 n. oraz powołaną tam literaturę. 
oznaczonych praw i obowiązków, mogą dodatkowo podlegać kontroli za pośrednictwem prawa procesowego w ramach postępowań administracyjnych i sądowych.

Biorąc pod uwagę powyższe niezbędne ustalenia w kwestii charakteru zadań Prezesa UZP uregulowanych w ustawie Prawo zamówien publicznych, można podjąć próbę określenia tych zadań już wyłącznie pod kątem interesujących nas zagadnień związanych z problematyką zapobiegania i zwalczania nadużyć wolności kontraktowej umów zawieranych w ramach zamówień publicznych. Nie jest to jednak łatwe przedsięwzięcie, zważywszy, że ustawa Prawo zamówień publicznych nastawiona jest głównie na regulację procesu wyłaniania kontrahentów dla podmiotów zobowiązanych do jej stosowania (zob. art. 3, 4a oraz 4b u.z.p.), a o ile normuje już zagadnienia dotyczące treści i granic swobody umów (zob. np. art. 140 i 144 u.z.p.), to raczej tylko w niewielkim stopniu i przy założeniu, że mogą one co najmniej potencjalnie wpływać na wynik postępowania w sprawie udzielenia zamówienia publicznego lub też jego późniejsze zniekształcenie (por. art. $139 \mathrm{i}$ n. oraz art. 140 ust. 3, art. $144 \mathrm{i}$ art. 146 u.z.p.) ${ }^{7}$. Wszakże, zgodnie $\mathrm{z}$ art. 1 u.z.p., ustawa określa zasady i tryb udzielania zamówień publicznych, środki ochrony prawnej, kontrolę udzielania zamówień publicznych oraz organy właściwe w sprawach uregulowanych w ustawie. Koncentracja uwagi prawodawcy wokół kwestii związanych z procedurą wyboru kontrahenta zamówienia publicznego oraz fragmentaryczne unormowania dotyczące treści umów bynajmniej jednak nie oznacza, że umowy zawierane w wyniku zamówień publicznych mogą być dowolnie kształtowane przez zamawiających oraz że prawo zamówień publicznych zachowuje całkowitą neutralność w kwestii zapobiegania i zwalczania dokonywanych przez nich nadużyć wolności kontraktowej zakresowo niewiążących się z naruszeniem reguł udzielania zamówienia publicznego oraz wyboru kontrahenta. W pierwszej kolejności należy stwierdzić, że zgodnie z art. 139 ust. 1 u.z.p. do umów w sprawach zamówień publicznych w zakresie odmiennie nieuregulowanym w ustawie Prawo zamówień publicznych stosuje się przepisy kodeksu cywilnego. Dotyczy to w szczególności przepisu art. $353^{1}$ k.c., który wyznacza granice wolności kontraktowej oraz przepisu art. 58 k.c., który w razie przekroczenia tych granic przewiduje sankcje nieważności bezwzględnej umowy w całości lub w części. Nieważność bezwzględna wywiera skutki prawne już na mocy samych odpowiednich przepisów, tj. bez konieczności wydawania konstytutywnych orzeczeń sądowych $^{8}$, przy czym skutki te mają charakter erga omnes, a więc działają nie

${ }^{7}$ Należy jednakże zauważyć, że ustawodawca nie realizuje tego założenia w pełni konsekwentnie, ponieważ prawo zamówień publicznych przewiduje również wiele przepisów odnoszących się do kształtowania treści umów neutralnych z tego punktu widzenia, a mających na celu jedynie ochronę interesu publicznego związanego z ochroną środków publicznych oraz ich racjonalnym wydatkowaniem (zob. w tym względzie np. art. 143a, art. 143b, art. 143c, art. 143d czy art. 145 u.z.p.).

${ }^{8}$ Orzeczenia sądowe w sprawach dotyczących bezwzględnej nieważności czynności prawnych w całości lub w części mają charakter wyłącznie deklaratoryjny, potwierdzający jedynie skutki 
tylko względem stron umowy, lecz także wobec osób trzecich i co do zasady każdy może się na nią powołać. Umowa lub jej część dotknięta sankcją nieważności bezwzględnej od samego początku (ab initio) dokonania czynności prawnej nie posiada mocy wiążącej, nie może być podstawą świadczeń, a jeżeli one już nastąpiły, strony zobowiązane są wzajemnie do ich zwrotu ${ }^{9}$. Na mocy art. 58 § 1 k.c. sankcja nieważności bezwzględnej w odniesieniu do naruszenia przepisów ustawy została jednak wyłączona $\mathrm{w}$ zakresie, $\mathrm{w}$ jakim właściwe przepisy przewidują inne skutki, co na gruncie prawa zamówień publicznych ma miejsce w sytuacji, gdy jej przepisy odsyłają do zastosowania sankcji unieważnienia umowy w całości lub w części. Ta szczególna sankcja w doktrynie określana jest również mianem nieważności względnej ${ }^{10} \mathrm{i}$ występuje w zamówieniach publicznych jedynie w następujących przypadkach:

1) naruszenia zakazu zawierania umowy w części wykraczającej poza określenie przedmiotu zamówienia wynikającego ze specyfikacji istotnych warunków zamówienia (art. 140 ust. 3 u.z.p.);

2) naruszenia zakazu wprowadzania istotnych zamian postanowień zawartej umowy w stosunku do treści oferty, na podstawie której dokonano wyboru wykonawcy, jeżeli możliwość dokonania takich zmian nie została przewidziana w ogłoszeniu o zamówieniu lub w jego specyfikacji istotnych warunków albo też wykracza poza dopuszczone warunki zmiany umowy (art. 144 ust. 2 u.z.p.);

3) naruszenia zakazu zastosowania trybu negocjacji bez ogłoszenia lub zamówienia z wolnej ręki (art. 146 ust. 1 pkt w zw. z ust. 2 pkt 1 oraz w zw. z art. 5 ust. 1 b, art. 10 ust. 2, art. 61 ust. 2 a contrario i art. 67 ust. 1 a contrario u.z.p.);

4) naruszenia nakazu umieszczenia ogłoszenia o zamówieniu w Biuletynie Zamówień Publicznych albo nakazu przekazania ogłoszenia o zamówieniu Urzędowi Publikacji Unii Europejskiej (art. 146 ust. 1 pkt 2 w zw. z art. 5a, art. 11 i n., art. 38 ust. 4 a, art. 40 ust. 2 i 3, art. 75 ust. 1 , art. 95 ust. 1 i 2 , art. 103 oraz art. 115 ust. 3 i 4 u.z.p.);

następujące z mocy działania samego prawa (ipso iure). Sądowe stwierdzenie nieważności czynności prawnej lub jej części może nastąpić w ramach postępowania wszczętego na podstawie art. 189 ustawy z dnia 17 listopada 1964 r. — Kodeks postępowania cywilnego (tekst jedn. Dz.U. 2014, poz. 101 z późn. zm., dalej: kpc) albo też mieć miejsce w ramach postępowania o zasądzenie świadczenia, w każdym jednak razie sąd z urzędu powinien uwzględnić zarzut nieważności bezwzględnej niezależnie od tego, kto się na taki zarzut powołuje. Pogląd ten podzielany jest w doktrynie, choć nie bez kontrowersji związanych z ograniczającą prawo materialne procedurą. Zob. bliżej na ten temat Z. Radwański, [w:] Prawo cywilne - część ogólna. System Prawa Prywatnego, Warszawa 2008, t. 2 , s. 443 n.

9 Na ten temat sankcji nieważności bezwzględnej zob. Z. Radwański, op. cit., s. 430; M. Gutowski, Nieważność czynności prawnej, Warszawa 2012, s. 369 n. oraz powołaną tam literaturę.

10 Zamiast wielu zob. M. Kania, [w:] System Prawa Administracyjneg. Publiczne Prawo..., t. 8B, s. 561 n.; J. Pieróg, Prawo zamówień publicznych. Komentarz, Warszawa 2015, passim, np. Komentarz do art. 144 in fine; oraz J. Jerzykowski, Komentarz do art. 146 ustawy - Prawo zamówień publicznych, [w:] W. Dzierżanowski, J. Jerzykowski, M. Stachowiak, Prawo zamówień publicznych. Komentarz, LEX 2012. 
5) naruszenia zakazu zawarcia umowy w terminie określonym w ustawie (dotyczy to tzw. okresu standstill), jeżeli uniemożliwiło to KIO uwzględnienie odwołania przed zawarciem umowy (art. 146 ust. 1 pkt 3 w zw. z art. 94 ust. 1 i art. 183 ust. 1 u.z.p.);

6) naruszenia nakazu umożliwienia składania ofert orientacyjnych wykonawcom niedopuszczonym wcześniej do udziału w dynamicznym systemie zakupów lub też naruszenia nakazu umożliwienia wykonawcom dopuszczonych do udziału w takim postępowaniu złożenia ofert (art. 146 ust. 1 pkt 4 w zw. z ust. 2 pkt 2 oraz w zw. z art. 107 i art. 108 u.z.p.);

7) naruszenia zakazu udzielenia zamówienia publicznego na podstawie umowy ramowej przed upływem przewidzianego w ustawie terminu, jeśli prowadzi to do naruszenia zawarcia umowy z uprawnionym wykonawcą (art. 146 ust. 1 pkt $5 \mathrm{w}$ zw. z ust. 2 pkt 2 oraz w zw. z art. 94 ust. 1 i art. 101 ust. 1 pkt 1 u.z.p.);

8) naruszenia zakazu zastosowania trybu zapytania o cenę (art. 146 ust. 1 pkt 6 w zW. $\mathrm{z}$ art. 70 a contrario u.z.p.);

9) naruszenia zakazu bezprawnego lub sprzecznego z dobrymi obyczajami wpłynięcia na wynik aukcji lub przetargu przez stronę umowy lub innego uczestnika takiego postępowania albo przez osobę działającą z nimi w porozumieniu (art. 146 ust. 5 u.z.p. w zw. $\mathrm{z}$ art. $70^{4}$ k.c.);

10) naruszenia zakazu dokonania przez zamawiającego określonej czynności lub nakazu jej zaniechania $w$ innych przypadkach przewidzianych w prawie zamówień publicznych, jeżeli takie zachowanie miało lub co najmniej mogło mieć wpływ na wynik postępowania (art. 146 ust. 6 u.z.p.).

Zgodnie $\mathrm{z}$ art. 146 ust. 4 u.z.p. oraz art. 58 ust. 1 k.c. $\mathrm{z}$ wymienionych powyżej przyczyn stanowiących przejawy naruszenia przepisów prawa zamówień publicznych nie można żądać stwierdzenia nieważności bezwzględnej umowy w całości lub w części ${ }^{11}$, a zatem zastosowania sankcji dalej idącej w stosunku do unieważnienia czynności prawnej. Choć podobnie jak nieważność bezwzględna, unieważnienie co do zasady wywołuje również skutek niweczący (ex tunc) ${ }^{12}$ od momentu dokonania czynności prawnej (zob. art. 146 ust. 3 u.z.p.), to w odróżnieniu od niej ów skutek nie następuje z mocy prawa, lecz wymaga konstytutywnego orzeczenia właściwego organu i wiąże w zasadzie tylko strony określonego postępowania uruchamianego jedynie w przypisanym terminie, po upływie które-

11 W wypadku niezawarcia jeszcze umowy dotyczy to odpowiednio wyliczonych enumeratywnie bezprawnych czynności prawnych zamawiającego o charakterze przedumownym, a także, co sprawia istotne trudności z rozgraniczeniem sankcji nieważności bezwzględnej i względnej, innych bezprawnych czynności zamawiającego stanowiących naruszenie prawa zamówień publicznych, jeżeli miały one lub co najmniej mogły mieć wpływ na dokonanie przez niego wyboru kontrahenta.

$12 \mathrm{Na}$ zasadzie wyjątku od zasady unieważnienie umowy w całości lub w części może jednak wywoływać skutki niweczące tylko na przyszłość (ex nunc), a mianowicie w uzasadnionych przypadkach — gdy nie jest możliwy zwrot świadczeń spełnionych na podstawie umowy podlegającej unieważnieniu albo utrzymanie umowy w mocy leży w ważnym interesie publicznym (zob. art. 146 ust. 3 w Zw. z art. 192 ust. 3 pkt 2 b oraz art. 192 ust. 5 in fine u.z.p.). 
go umowa z przyczyn podlegających unieważnieniu staje się niewzruszalna (por. art. 144a ust. 2 i art. 146 ust. 4 u.z.p.). Ponadto w przeciwieństwie do nieważności bezwzględnej, której potwierdzenia w postępowaniu sądowym może domagać się każdy, kto ma w takim ustaleniu interes prawny (zob. art. $189 \mathrm{kpc}$ ), unieważnienia umowy w całości lub w części zarówno w postępowaniu quasi sądowym ${ }^{13}$ przed $\mathrm{KIO}$, jak i w postępowaniu sądowym mogą domagać się jedynie podmioty legitymowane według reguł określonych w ustawie Prawo zamówień publicznych. Katalog tych podmiotów został jednak wyznaczony stosunkowo szeroko, gdyż obejmuje on wykonawców, uczestników konkursu oraz inne podmioty, które mają lub miały interes w uzyskaniu danego zamówienia publicznego oraz poniosły lub mogły ponieść szkodę w wyniku naruszenia przez zamawiającego prawa zamówień publicznych, a w zakresie naruszeń związanych z ogłoszeniem zamówienia publicznego oraz specyfikacją istotnych warunków zamówienia rozciąga się on również na organizacje wpisane na listę prowadzoną przez Prezesa UZP (zob. art. 179 i art. 198a u.z.p.). Ponadto w skład tego katalogu należy zaliczyć wykonawców, którzy przystąpili do toczącego się już postępowania uruchamiającego ochronę prawną przewidzianą w ustawie (zob. art. 185 ust. 2 i 3 u.z.p.), a także podmiot szczególny, jakim jest Prezes UZP (zob. art. 168 oraz art. 198b ust. 4 w zW. z art. 198a ust. 1 u.z.p.). Jednakże jedynie Prezes UZP uprawniony jest do żądania unieważnienia umów zawartych w zamówieniach publicznych poniżej tzw. progu unijnego, a pozostałe podmioty tylko w wypadku naruszenia przez zamawiającego zakazu wyboru trybu negocjacji bez ogłoszenia, zakazu zamówienia z wolnej ręki lub trybu zapytania o cenę, naruszenia przepisów regulujących opis sposobu oceny spełniania warunków udziału w postępowaniu o uzyskanie zamówienia publicznego, a także w razie wykluczenia uczestnika takiego postępowania lub odrzucenia jego oferty (zob. art. 180 ust. 2 u.z.p.). Sankcja unieważnienia umowy zawartej w wyniku zamówienia publicznego nie może być natomiast zastosowana przez organ orzekający z urzędu. Nieuzasadnione sa w tej kwestii zapatrywania przeciwne ${ }^{14}$, wykluczające, z wyjątkiem Prezesa UZP, legitymację wskazanych wyżej podmiotów do żądania unieważnienia umowy. Zawarcie umowy następuje wprawdzie już poza procedurą wyboru kontrahenta, ale pozostaje z nim w bezpośrednim związku i mieści się w ramach postępowania o udzielenie zamówienia publicznego. Poza tym podkreślenia wymaga, że ustawa Prawo zamówień publicznych wyraźnie stanowi, iż organy właściwe w sprawach unieważ-

13 Krajowa Izba Odwoławcza (KIO), właściwa do rozpoznawania odwołań od decyzji zamawiającego zarówno polegających na działaniu, jak i zaniechaniu, nie jest sądem w rozumieniu przepisów Konstytucji RP (zob. art. 173 n.). Nie sprawuje więc wymiaru sprawiedliwości i nie orzeka w imieniu Rzeczypospolitej Polskiej, lecz w sprawach odmiennie nieuregulowanych w ustawie Prawo zamówień publicznych stosuje się do niej odpowiednio przepisy kodeksu postępowania cywilnego o sądzie polubownym (zob. art. 187 ust. 8 u.z.p.).

14 Zob. np. R. Szostak, Zmiany w zakresie środków ochrony prawnej wykonawców ubiegajacych się o zamówienie publiczne, „Prawo Zamówień Publicznych”2010, nr 1, s. 10 n. 
nienia umowy w całości lub części albo unieważnienia przedumownych czynności prawnych zamawiającego nie mogą orzekać ponad żądanie (zob. art. 192 ust. 7 oraz art. 198a ust. 2 u.z.p. w zw. z art. 321 kpc).

Jak już wcześniej zaznaczono, Prezes UZP pełni szczególną rolę w przeciwdziałaniu i zwalczaniu niedozwolonych czynności zamawiających, ponieważ wypełniając powierzone mu ustawą zadania, działa na rzecz ochrony interesu publicznego. W odróżnieniu od innych podmiotów jedynie uprawnionych do korzystania ze środków ochrony prawnej przewidzianych w prawie zamówień publicznych, Prezes UZP stoi na straży przestrzegania tego prawa i jego ustawowe uprawnienia należy postrzegać w kategoriach obowiązku. Wprawdzie na gruncie zamówień publicznych ochrona interesu publicznego w znacznej mierze jest zapewniana wysiłkiem ubiegających się o zamówienia finansowane ze środków publicznych i realizowana na koszt ${ }^{15}$ podmiotów wytykających naruszenia prawa we własnym interesie, nie ma jednak podstaw normatywnych, aby działania Prezesa UZP na rzecz ochrony interesu publicznego w drodze postępowania przed właściwymi organami można było uznać za mające wyłącznie charakter akcesoryjny. Biorąc pod uwagę dane statystyczne aktywności Prezesa UZP na tym polu w porównaniu z danymi obrazującymi aktywność procesową uczestników postępowań w sprawach zamówień publicznych, można jednak mieć wątpliwość odnośnie do wiodącej roli Prezesa UZP w ochronie interesu publicznego oraz zapewniania przez jego urząd zarówno skuteczności tej ochrony, jak i bezpieczeństwa obrotu związanego z rynkiem zamówień publicznych ${ }^{16}$. Niedomagania inicjatywy Prezesa UZP w zakresie ochrony interesu publicznego widoczne są zwłaszcza na płaszczyźnie przeciwdziałania i zwalczania nadużyć wolności kontraktowej we wzorcach umownych stosowanych przez zamawiających w zamówieniach publicznych. Jak się wydaje, są one spowodowane niedocenianiem zagrożeń płynących z takich nadużyć dla konkurencyjności rynku zamówień publicznych, którą bezsprzecznie należy zaliczyć do podstawowych wartości chronionych przez porząadek prawny. W tym kontekście zastrzeżenia może ponadto budzić rozwiązanie co do zasady wyłączające możliwość domagania się przez uczestników postepowań w sprawach zamówień publicznych unieważnienia umów zawartych z naruszeniem prawa w ramach procedur organizowanych poniżej tzw. progu unijnego (art. 180 ust. 2 u.z.p.). W związku z sygnalizowaną biernością Prezesa UZP największym jednak problemem w systemie szeroko rozumianego nadzoru nad rynkiem zamówień publicznych w Polsce jest ustawowe zablokowanie w nieokreślonym bliżej, lecz de facto w pełnym zakresie, możliwości podważenia na zasadach ogólnych skuteczności umowy w całości lub w części ze względu na nadużycie wolności kontraktowej

15 Zob. przepisy Rozporządzenia Prezesa Rady Ministrów z dnia 15 marca 2010 r. w sprawie wysokości i sposobu pobierania wpisu od odwołania oraz rodzajów kosztów w postępowaniu odwoławczym i sposobu ich rozliczania (Dz.U. $2010 \mathrm{Nr} 41$ poz. 238).

16 Por. dane ze sprawozdań rocznych Prezesa UZP i KIO za ostatnie 5 lat opublikowane na www.uzp.gov.pl oraz www.uzp.gov.pl/kio. 
przez zamawiających (zob. art. $353^{1} \mathrm{w}$ zW. z art. 58 k.c. i art. 189 k.p.c.; por. art. 146 ust. 4 i 6 u.z.p.). O ile można bowiem znaleźć argumenty uzasadniające wyłączenie sankcji nieważności czynności prawnych względem ściśle oznaczonych naruszeń prawa zamówień publicznych (art. 146 ust. 1 u.z.p.), o tyle posłużenie się przez ustawodawcę klauzulą generalną wszelkich innych naruszeń prawa zamówień publicznych, jeśli miało ono lub mogło mieć wpływ na wynik postępowania (art. 146 ust. 6 u.z.p.), budzi istotne zastrzeżenia. Nieokreśloność tego ustawowego wyrażenia powoduje, że w zasadzie każde nadużycie wolności kontraktowej potencjalnie może zostać zakwalifikowane w ten sposób, np. w rezultacie stwierdzenia niezachowania reguł uczciwej konkurencji (zob. art. 146 ust. 6 w zw. z art. 7 ust. 1 u.z.p.). Naruszenie tego rodzaju reguł zawsze może wystąpić w wypadku narzucenia we wzorcu umownym nieuczciwych postanowień umownych, co może mieć miejsce także wówczas, gdy nieuczciwe postanowienia umowne formalnie adresowane są jednakowo względem wszystkich uczestników postępowania w sprawie zamówienia publicznego ${ }^{17}$. Przynajmniej hipotetycznie nie można bowiem wykluczyć, że do danego postępowania zgłosiłoby się więcej uczestników, gdyby w jego dokumentacji nie zamieszczono nieuczciwych postanowień umownych albo też że uczestnicy postępowania w sprawie zamówienia publicznego zgłosiliby oferty innej treści, w szczególności bardziej korzystne cenowo, co w rezultacie mogłoby prowadzić do odmiennego rozstrzygnięcia wyniku postępowania. Na gruncie unormowań zamówień publicznych rozdział pomiędzy sankcją nieważności względnej i bezwzględnej został więc przeprowadzony wadliwie, powodując w obrocie dużą niepewność prawną oraz nieprzewidywalność rozstrzygnięć. Stanowi on również podstawę mylnego przekonania, że nadużycia wolności kontraktowej powiązane z naruszeniem prawa zamówień publicznych są wszechstronnie zwalczane, zarówno przez Prezesa UZP, jak i uczestników zamówień publicznych. Tymczasem Prezes UZP bardzo rzadko korzysta z kompetencji żądania unieważnienia umowy w całości lub w części, a podmioty uczestniczące w zamówieniach publicznych obiektywnie nie są zainteresowane zwalczaniem nieuczciwych klauzul umownych na etapie ubiegania się o zamówienie publiczne. Nie mają one bowiem żadnych gwarancji prawnych, że zaskarżenie czynności zamawiającego przyniesie im efekt w postaci zdobycia zamówienia publicznego. Zwycięzca postępowania w sprawie udzielenia zamówienia publicznego nie ma natomiast interesu w kwestionowaniu przedumownych czynności zamawiających, zanim konkretne zamówienie nie zostanie ostatecznie rozstrzygnięte na jego korzyść. Trzeba mieć tutaj na względzie, że rolą uczestników rynku zamówień publicznych nie jest napominanie zamawiających, zwłaszcza że w powszechnym odczuciu społecznym mogą oni obawiać się z ich strony pewnych retorsji przy podejmowaniu decyzji w sprawie wyboru kontrahenta. Kwestionowanie nieuczciwych postanowień umownych w zamówieniach pu-

17 Por. W. Dzierżanowski, Ochrona konkurencji w prawie zamówień publicznych, LEX 2012. 
blicznych następuje więc przeważnie dopiero na etapie realizacji umowy zawartej przez zamawiającego ze zwycięzcą postępowania ${ }^{18}$. Jest to uzasadnione, zważywszy na okoliczność, że na tym etapie możliwa jest pełniejsza wykładnia postanowień umownych wzbogacona praktyką wykonywania umowy, co w trakcie jedynie abstrakcyjnej kontroli wzorców umownych stosowanych przez zamawiających obiektywnie nie może mieć miejsca. Jednakże kontrola nieuczciwych postanowień umownych przeprowadzana in concreto z inicjatywy stron umowy zawartej $\mathrm{w}$ ramach zamówienia publicznego napotyka na istotną przeszkodę $\mathrm{w}$ postaci nieokreśloności art. 146 ust. 6 u.z.p., który de facto na mocy art. 146 ust. 4 u.z.p. całkowicie blokuje taką kontrolę. Nierzadko bezkrytycznie przyjmuje się przy tym, że skoro prezes UZP w ramach swoich kompetencji nie wystąpił z urzędu o unieważnienie czynności zamawiającego w całości lub w części, to są one zgodne z porządkiem prawnym ${ }^{19}$. W rezultacie zarówno podmioty ubiegające się o zamówienia publiczne, jak i podmioty otrzymujące już zamówienia, a także Prezes UZP nie przeciwstawiają się nadużyciom wolności kontraktowej stosowanym przez zamawiających, co zaowocowało istotnym zwiększeniem i rozpowszechnieniem się różnego rodzaju nieuczciwych postanowień wzorców umownych na rynku zamówień publicznych. Tytułem przykładu można wskazać na zastrzeganie przez zamawiających prawa do niezrealizowania przez siebie zamówienia publicznego w całości, kreowanie uprawnienia do jednostronnej zmiany umowy na podstawie subiektywnych kryteriów zależnych od woli zamawiających, wyłączanie ustawowo zagwarantowanych uprawnień wykonawców do żądania zmiany ceny lub wysokości wynagrodzenia, narzucanie wykonawcom dodatkowych zobowiązań niemających rzeczowego związku z zamówieniem publicznym, wymuszanie na wykonawcach zrzeczenia się roszczeń wobec zamawiających z tytułu zdarzeń powstałych przez zawarciem umowy, a także składania oświadczeń gwarancyjnych, że ich oferta stanowi akceptację przedłożonej przez zamawiających dokumentacji projektowej i zawiera wszystko co niezbędne do wykonania wszystkich prac oraz że cena nie zmieni się nawet $\mathrm{w}$ wypadku powierzenia dodatkowych robót, jeśli są one niezbędne do dokończenia wszystkich prac, przerzucanie ryzyka oraz kosztów własnej działalności na wykonawców zamówień publicznych, uzależnianie wymagalności należności wykonawców od aktów woli zamawiających czy wydłużanie płatności faktur ponad dopuszczalne granice przewidziane $\mathrm{w}$ ustawie o terminach zapłaty ${ }^{20}$. Przeświadczenie o uprzywilejowanej faktycznie

${ }^{18}$ Nie funkcjonuje natomiast zupełnie system zapobiegania nieuczciwości kontraktowej w zamówieniach publicznych.

19 Pomijając fakt, że taki stan rzeczy może wynikać również z nieprawidłowego wykonywania zadań przez Prezesa UZP, należy zauważyć, iż w odróżnieniu od innych przypadków naruszenia prawa zamówień publicznych na podstawie art. 146 ust. 6 u.z.p. Prezes UZP może bezterminowo żądać unieważnienia umowy w całości lub części (por. art. 144a u.z.p.).

${ }^{20}$ Zob. ustawę z dnia 8 marca 2013 r. o terminach zapłaty w transakcjach handlowych (Dz.U. 2013 poz. 403 z późn. zm.). 
pozycji kontraktowej zamawiających oraz o bezkarności wymienionych praktyk doprowadziły do swoistej eksplozji różnego rodzaju pomysłów mających rzekomo na względzie racjonalizację wydatków publicznych. Finansowanie zadań ze środków publicznych i dążenie do zabezpieczenia interesów zamawiających nie może jednak usprawiedliwiać stosowania przez nich nieuczciwych praktyk kontraktowych. Brak jest jakichkolwiek podstaw, aby interes zamawiających utożsamiać z interesem publicznym, uosabiającym różne wartości prawnie chronione określane mianem dobra wspólnego ${ }^{21}$. Jedną z tych wartości bezsprzecznie jest uczciwość kontraktowa, którą zobowiązani są przestrzegać wszyscy uczestnicy obrotu bez względu na swój status i pozycję. Za nieuprawnione należy uznać również zapatrywanie, że racjonalne wydatkowanie środków publicznych wymaga od zamawiających narzucania postanowień umownych w sposób zapewniający im supremację kontraktową. Oparte jest ono na błędnych przesłankach, ponieważ $\mathrm{w}$ istocie stanowi wyzyskiwanie przewagi związanej z trybem zawierania umów, które jeśli przybiera nieuczciwą postać, prowadzi do rozwoju postaw antykonkurencyjnych oraz różnych innych patologicznych zjawisk, które nierzadko per saldo wiążą się ze zwiększeniem wydatków publicznych, a więc z wystąpieniem efektu przeciwnego do zamierzonego. Pozycja kontraktowa zamawiających oraz wydatkowanie przez nich środków publicznych nie zwalniają ich zatem z przestrzegania granic wolności umów przy kształtowaniu stosunków umownych, zwłaszcza że obowiązujące przepisy prawa powszechnego oraz prawa zamówień publicznych umożliwiają zamawiającym zabezpieczenie swoich interesów w sposób zgodny z regułami uczciwości kontraktowej.

Podsumowując dotychczasowe rozważania, można sformułować kilka wniosków i postulatów zarówno o charakterze de lege lata, jak i de lege ferenda. Przede wszystkim należy stwierdzić, że na rynku zamówień publicznych nie tylko nie zapobiega się nadużyciom wolności kontraktowej, ale również nie zwalcza się skutecznie ich przejawów w tych wszystkich obszarach, które nie zostały bezpośrednio uregulowane i sankcjonowane w prawie zamówień publicznych, lecz zostały objęte klauzulą generalną określoną w art. 146 ust. 6 u.z.p. Nadużyciom wolności kontraktowej sprzyja sposób zawierania umów przez zamawiających związany ze stosowaniem jednostronnych wzorców umownych, faktyczny brak możliwości sądowego stwierdzenia nieważności nieuczciwych postanowień umownych przez wykonawców, tolerowanie nadużyć motywowane koniecznością ochrony wadliwie pojmowanej racjonalności wydatkowania i zabezpieczenia środków publicznych, a także niedostateczna aktywność Prezesa UZP, który został wyposażony $\mathrm{w}$ różne kompetencje nadzorujące rynek zamówień publicznych w Polsce oraz inicjujące jego prawną regulację. Ponieważ kompetencje Prezesa UZP do żądania unieważnienia umowy w całości lub w części przewidziane w art. 146 ust. 6 u.z.p.

${ }^{21}$ Na temat pojęcia interesu publicznego zob. w szczególności A. Żurawik, [w:] System Prawa Administracyjnego. Publiczne Prawo..., t. 8A, s. 410 n. oraz powołaną tam literaturę. 
blokują de facto możliwość sądowego stwierdzenia nieważności czynności prawnych zamawiających na zasadach ogólnych, de lege lata należy postulować zwiększenie aktywności i efektywności działań Prezesa UZP na tym polu, a także w obszarze jego zadań o charakterze edukacyjno-szkoleniowym. Konieczne jest zwłaszcza uświadomienie wpływu nieuczciwych postanowień umownych na zmniejszenie konkurencyjności rynku zamówień publicznych oraz występowania na nim innych negatywnych skutków. Nie tylko dla zwalczania nadużyć wolności kontraktowej, ale również ich zapobiegania Prezes UZP powinien również w znacznie większym stopniu niż dotychczas korzystać z opracowywania dobrych praktyk kontraktowych $\mathrm{w}$ zamówieniach publicznych oraz z ustalania przykładowych wzorców umownych wolnych od nieuczciwych postanowień i innych naruszeń prawa powszechnego. Z kolei de lege ferenda należy opowiedzieć się za uchyleniem w całości art. 146 ust. 6 u.z.p. oraz innych przepisów prawa zamówień publicznych w części zawierającej odesłanie do wymienionego przepisu. Dotyczy to w szczególności art. 146 ust. 4 u.z.p., który w zakresie określonym w art. 146 ust. 6 u.z.p. bezterminowo wyłącza możliwość stwierdzenia nieważności umowy w całości lub w części na postawie art. 189 kpc. Niezależnie od wskazanych mankamentów wymienionych przepisów oraz ich szkodliwego działania należy zwrócić uwagę, że formalnie mogą one zostać uznane za niezgodne z art. 2 i 31 ust. 3 Konstytucji RP z powodu niedostatecznej określoności w związku z naruszeniem zasad demokratycznego państwa prawa oraz naruszeniem zasad niezbędności i proporcjonalności ograniczeń konstytucyjnych wolności i praw ${ }^{22}$. Jednocześnie można rozważyć poszerzenie zakresu enumeratywnie wymienionych i skonkretyzowanych naruszeń prawa zamówień publicznych kwalifikujących się do unieważnienia czynności zamawiających w całości lub części, a także upoważnić Prezesa UZP nie tylko do żądania zastosowania tej sankcji na drodze postępowania przed właściwymi organami, tak jak ma to miejsce $\mathrm{w}$ aktualnie obowiązującym stanie prawnym, ale również do żądania stwierdzenia nieważności umowy w całości lub w części na zasadach ogólnych w związku z innymi nadużyciami wolności kontraktowej. W interesie publicznym leży bowiem systematyczne zwalczanie i przeciwdziałanie wszelkim przejawom nadużyć wolności kontraktowej, a nie tylko niektórym jej postaciom. Ponieważ w odróżnieniu od sankcji nieważności, sankcja unieważnienia czynności prawnych jest ograniczona dopuszczalnym czasem jej realizacji, powinna dotyczyć jedynie ściśle oznaczonych naruszeń prawa odnoszących się do procedury zamówień publicznych i wyboru kontrahenta. Sankcja nieważności powinna natomiast obejmować wyłącznie naruszenia odnoszące się do treści i celu czynności prawnych i być dostępna dla każdego, kto ma interes prawny $\mathrm{w}$ ustaleniu istnienia lub nieistnienia określonego prawa lub

${ }^{22}$ Zob. przegląd orzecznictwa dotyczącego tych zagadnień, Proces prawotwórczy w świetle orzecznictwa Trybunału Konstytucyjnego, Zasada określoności przepisów prawa, s. 54 n., Opracowanie Biura Trybunału Konstytucyjnego, Warszawa 2013, s. 54 n. 
stosunku prawnego. W efekcie proponowanych zmian wykonawcy zamówień publicznych będą mogli więc przeciwstawić się nadużyciom wolności kontraktowej stosowanym przez zamawiających w trakcie realizacji umów, niezależnie od należytego wykonywania zadań powierzonych Prezesowi UZP.

\section{THE ROLE OF THE PUBLIC PROCUREMENT CHAMBER CHAIRMAN IN PREVENTION AND ELIMINATION OF THE FREEDOM OF CONTRACT ABUSE IN PUBLIC PROCUREMENT CONTRACTS}

\section{Summary}

The study examines the actual and postulated role of the Chairman of Public Procurement Chamber in prevention and eradication of freedom of contract abuse, which is not directly related to the infringement of public procurement law but civil law and other law branches. The issue has not been analyzed by the doctrine, even though the practice of contracting authorities in public procurement standard agreements often leads to freedom of contract abuse, which is tolerated by the Chairman of Public Procurement Chamber. Taking into consideration the dimension of detrimental results not only for the economy but also public finance, the body which supervises the public procurement market should have broader competences. Localizing all the protection against unfair and illegal standard agreement provisions only in courts of law as well as relinquishment of the prevention measures is an ineffective, inappropriate and systemically unjustified solution. 